\title{
A new Upper Cretaceous species of Chresmoda from Lebanon - a latest representative of Chresmodidae (Insecta: Polyneoptera inc. sed.): first record of homeotic mutations in the fossil record of insects
}

\author{
ANDRÉ NEL ${ }^{1}$, DANy AZAR ${ }^{2}$, XAVIER MARTÍNEZ-DELCLÒS³ and EdouARD MAKHOUL ${ }^{4}$ \\ ${ }^{1}$ Laboratoire d'Entomologie and CNRS UMR 8569, Muséum National d'Histoire Naturelle, 45 Rue Buffon, F-75005 Paris, France; \\ e-mail: anel@mnhn.fr \\ ${ }^{2}$ Lebanese University, Faculty of Science II, , Biology Department, Fanar - Matn - B.P. 26110217, and Saint-Joseph University, \\ Campus of Sciences and Technology, Mar Roukos (Mkalles), B.P. 11-1514 Beirut, Lebanon; e-mail: azar@mnhn.fr \\ ${ }^{3}$ Departament d'Estratigrafia, Paleontologia i Geociències Marines, Facultat de Geologia, Universitat de Barcelona, E-08071, \\ Barcelona, Spain; e-mail: xdelclos@geo.ub.es \\ ${ }^{4}$ Saint-Joseph University, B.P 165507, Beyrouth, Lebanon; e-mail: maked@cyberia.net.lb
}

Key words. Insecta, Polyneoptera, Chresmodidae, Cenomanian, Lebanon, systematic palaeontology, Palaeoecology, leg morphology, pleustonic life

\begin{abstract}
The most recent representative of the semi-aquatic insect family Chresmodidae is described from the Lebanese Cenomanian marine lithographic limestone. Its highly specialized legs, with a high number of tarsomeres, never observed in other orders of insects, were probably adapted for water surface skating. We hypothesize the occurrence of a unique, extraordinary "antenna" mutation affecting the distal part of the legs of the Chresmodidae, maybe homeotic or affecting some genes that participate in the leg development and segmentation. The Chresmodidae had a serrate ovipositor adapted to endophytic egg laying in floating or aquatic plants. They were probably predaceous on nektonic small animals. As the Chresmodidae and the aquatic water skaters of the bug families Veliidae and Gerridae were contemporaneous during at least the Lower Cretaceous, these insects probably did not cause the extinction of this curious group.
\end{abstract}

The Mid Cenomanian "fish beds" of Nammoura, Lebanon, contain a rich and diverse fauna of marine fishes, aquatic and terrestrial reptiles, bird remains, some small crustaceans (Schram et al., 1999), cephalopods, coprolithes and small fecal pellets. A well-preserved plant assemblage was also described, with aquatic ferns, gymnosperms, and angiosperm flowers and leaves (Krassilov $\&$ Bacchia, 2000). Despite the presence of these terrestrial plant remains in this "lithographic" limestone, no insect was recorded from this outcrop, except for an indication of the presence of a beetle, not confirmed yet. One of us (E.M.) has found recently three well-preserved chresmodid larval exuviae and another larva, which we describe now. These fossils are the most recent Chresmodidae and its first record for the Middle East. They are of great interest for the palaeoautoecology and palaeobiogeography of this enigmatic group and the reconstruction of the palaeoenvironment of the Nammoura "fish beds".

Family Chresmodidae Handlirsch, 1908

Polyneoptera of uncertain position (after Rasnitsyn, 2002)

Type genus. Chresmoda Germar, 1839.

Type species. Chresmoda obscura Germar, 1839 (Tithonian, Upper Jurassic, lithographic limestone, Solnhofen, Germany).

Other species. Chresmoda aquatica Martínez-Delclós, 1989 (Barremian, Rasnitsyn \& Martínez-Delclòs, 2000, Montsec, Lleida, Spain); Chresmoda orientalis Esaki, 1949 (Early Cretaceous, Rasnitsyn, 2002, Lingyen-hsien, Jehol Province, China); Chresmoda libanica sp. $\mathrm{n}$. The Chresmodidae are also present in the Aptian Santana palaeolake (Brazil) (Bechly, pers. comm.), and in the Middle or Late Jurassic of Bakhar in Mongolia (Rasnitsyn, 2002).

Other genus. Saurophthiroides Ponomarenko, 1986.

\section{Chresmoda libanica sp. $\mathbf{n}$.}

Figs 1-14

Material. Holotype specimen NI 3a-b, paratypes specimens NI 1a-b, NI 2a-b, and NI 4 (Nammoura Insect), collection Edouard Makhoul, Beyrouth, Lebanon.

Type locality. Nammoura, El Ghabour valley, Caza Kesrouâne, Mouhafazit Jabal Loubnan (Mont-Liban district), Lebanon.

Stratigraphic horizon. Mid-Cenomanian, Upper Cretaceous. Etymology. After Lebanon.

Diagnosis. Differing from other Chresmoda spp. in the following characters: prothoracic tibia very short, representing $23 \%$ of femoral length; tarsi with a high number of tarsomeres, about 18 in prothoracic legs and more than 40 in meso- and metathoracic legs.

Description. Specimens NI 1, NI 2, and NI 4 are nymphal exuviae because their thoraces are dorsally opened. Specimen NI 3 is a nymph visible from ventral surface. NI 4 is smaller than the other specimens and has no visible ovipositor (younger nymph or male specimen?). Body $13.0 \mathrm{~mm}$ long (including ovipositor), $5.4 \mathrm{~mm}$ wide (NI 3), $9.5 \mathrm{~mm}$ long, $4.0 \mathrm{~mm}$ wide (NI 2), $11.6 \mathrm{~mm}$ long, $4.8 \mathrm{~mm}$ wide (NI 1); $4.0 \mathrm{~mm}$ long, $2.8 \mathrm{~mm}$ wide (NI 4).

The heads are poorly preserved, $2.3 \mathrm{~mm}$ long, $2.4 \mathrm{~mm}$ wide (NI 3). Two structures are visible, $0.8 \mathrm{~mm}$ long and 


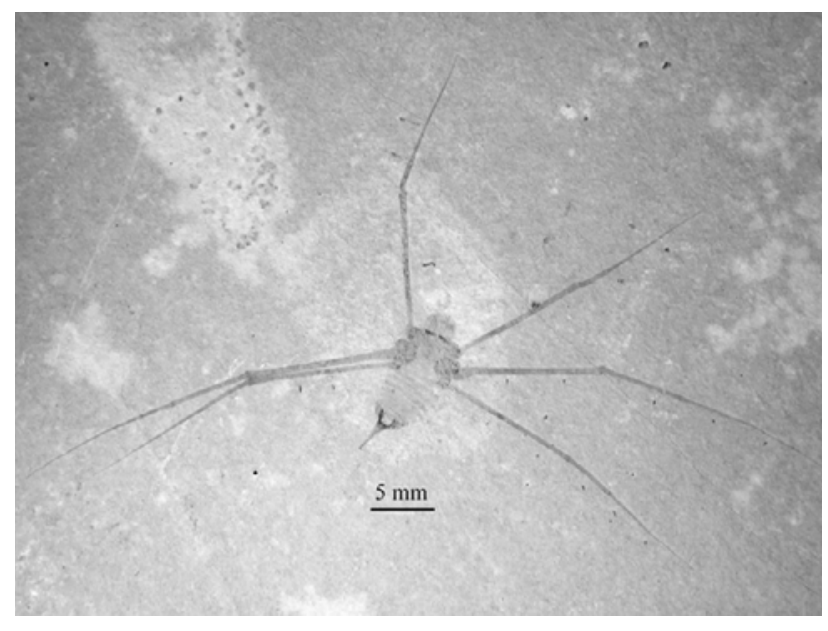

Fig. 1. Chresmoda libanica sp. n., holotype specimen NI 3a, photograph of general habitus.

$0.2 \mathrm{~mm}$ wide, bearing about 20 long and sharp spines (Fig. 10), probably corresponding to maxillary palpi. These structures are better preserved in specimens NI 1 and NI 2 than in NI 3. A short two- or three-segmented labial palpus is visible in NI 3, with no visible setae, about $1.0 \mathrm{~mm}$ long; mandibles visible in NI $3,0.7 \mathrm{~mm}$ long and $0.5 \mathrm{~mm}$ wide, bearing a row of small obtuse teeth and several short but sharp spines (Figs 3-4). The eyes are visible in NI 3, large elliptic, about $1.2 \mathrm{~mm}$ long and $0.8 \mathrm{~mm}$ wide, $0.8 \mathrm{~mm}$ apart. The antennae are not visible, probably not preserved.

The thorax is rather rounded but with a strong posterior concavity in ventral view, $4.0 \mathrm{~mm}$ long, $5.4 \mathrm{~mm}$ wide (NI 3), $2.5 \mathrm{~mm}$ long, $4.0 \mathrm{~mm}$ wide (NI 1), $2.5 \mathrm{~mm}$ long, 4.8 $\mathrm{mm}$ wide (NI 2), with no visible wing sheaths.

The legs are very long and narrow, covered with very small hairs arranged in rows (visible in NI 2). The pairs of coxae are widely separated, $2.5 \mathrm{~mm}$ apart (NI 3), all similar, those of the same side of thorax being very close to each other, rounded and large, $0.8 \mathrm{~mm}$ wide and long. The trochanters are small and short, all similar, $0.5 \mathrm{~mm}$

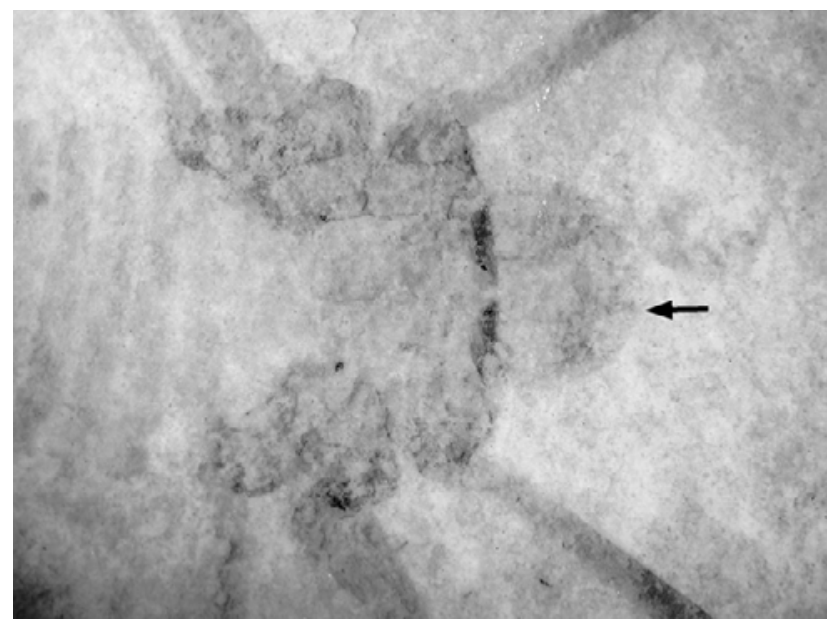

Fig. 3. Chresmoda libanica sp. n., holotype specimen NI 3a, photograph of head and thorax, arrow indicates right mandible with an apical short spine.

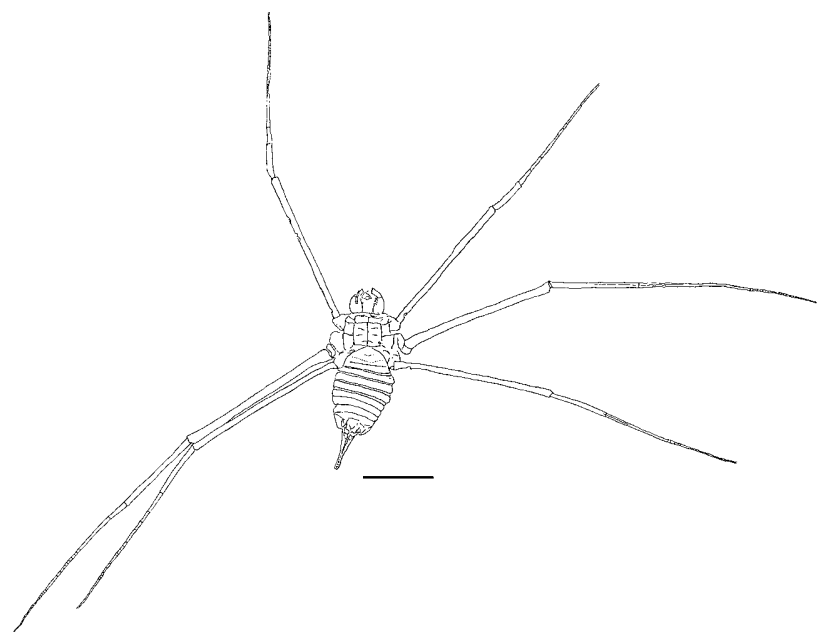

Fig. 2. Chresmoda libanica sp. n., holotype specimen NI 3a, drawing of general habitus, scale bar represents $5 \mathrm{~mm}$.

long. The prothoracic femora are straight and elongate, $10.7 \mathrm{~mm}$ long, $0.45 \mathrm{~mm}$ wide, bearing a short anterior process and a series of small apical spines. The prothoracic tibiae have a curved base, very short, $2.5 \mathrm{~mm}$ long, $0.4 \mathrm{~mm}$ wide, representing the $23 \%$ of femoral length. There is a row of small spines at tibial apex. The whole prothoracic tarsus is $10.0 \mathrm{~mm}$ long, first tarsomere 3.0 $\mathrm{mm}$ long, second tarsomere about $2.5 \mathrm{~mm}$ long, third about $1.0 \mathrm{~mm}$ long. The more distal segmentation of

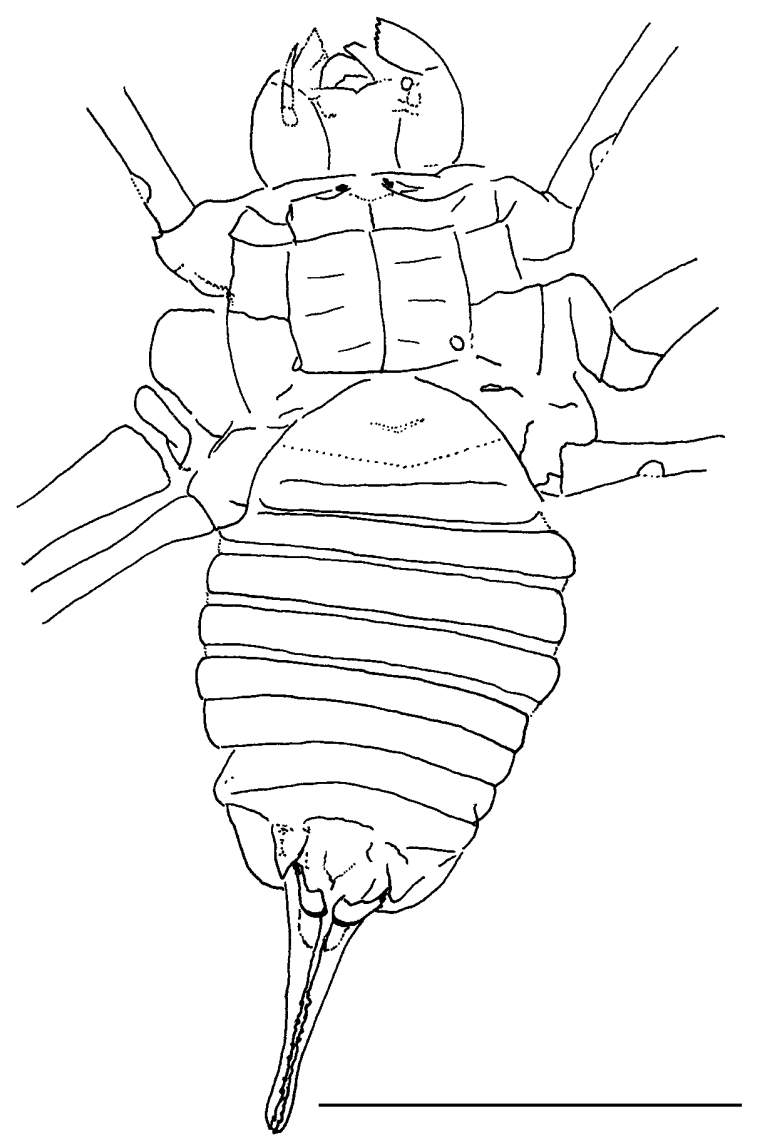

Fig. 4. Chresmoda libanica sp. n., holotype specimen NI 3a, drawing of ventral view of the body. Scale bar represents $5 \mathrm{~mm}$. 
tarsus is less distinct, except for presence of numerous, more than 15 very small apical tarsomeres of decreasing lengths. The mesothoracic femora are elongate, $12.3 \mathrm{~mm}$ long, $0.55 \mathrm{~mm}$ wide, bearing a short round anterior process. The mesothoracic tibiae are $6.7 \mathrm{~mm}$ long, $0.4 \mathrm{~mm}$ wide, representing the $54 \%$ of femoral length. The whole tarsus is $14.0 \mathrm{~mm}$ long, first tarsomere about $2.9 \mathrm{~mm}$ long, second about $0.7 \mathrm{~mm}$ long. There are 40-50 more distal tarsomeres, all short and of decreasing lengths, the most apical tarsomeres being very small. The metathoracic femora are elongate, $12.0 \mathrm{~mm}$ long, $0.4 \mathrm{~mm}$ wide, bearing a short anterior process. The tibiae are $4.4 \mathrm{~mm}$ long, $0.35 \mathrm{~mm}$ wide, representing $36.6 \%$ of femoral length. The whole tarsus is $9.4 \mathrm{~mm}$ long, 40-50 short tarsomeres of decreasing lengths, the most apical tarsomeres being very small. All tarsi have a weak longitudinal median carina, as in C. aquatica. The distal margins of all tarsomeres are oblique, sigmoidal, and with a small spine. The tarsal claws are absent.

The abdomen has nine visible sternites (NI 3), $6.2 \mathrm{~mm}$ long, $4.4 \mathrm{~mm}$ wide (NI 3), $5.0 \mathrm{~mm}$ long, $3.1 \mathrm{~mm}$ wide (NI 1), $4.0 \mathrm{~mm}$ long, $2.4 \mathrm{~mm}$ wide (NI 2). There are two small dark cerci, apparently one-segmented and sharp, 0.5 $\mathrm{mm}$ long, and $0.18 \mathrm{~mm}$ wide at base. The ovipositor is long, well preserved in NI 3, with valvulae V1 $2.7 \mathrm{~mm}$ long, each $0.3 \mathrm{~mm}$ wide at mid length and bearing a row of about 18 strong inner indentations. The ovipositor valvulae V2 are visible at base of the V1, $0.6 \mathrm{~mm}$ long, and $0.3 \mathrm{~mm}$ wide. The valvulae V3 are very small at base of $\mathrm{V} 1,0.2 \mathrm{~mm}$ long, and $0.3 \mathrm{~mm}$ wide (Figs 5-6).

Discussion. The three female specimens are nearly of the same size and shape and the hypothetical male is slightly smaller. They belong to the same species. They closely resemble the nymphs ascribed to Chresmoda aquatica and C. obscura (Martínez-Delclòs, 1991; also specimen figured in Frickhinger, 1994: Fig. 275), and Saurophthiroides mongolicus Ponomarenko, 1986. Thus, we ascribe them to the genus Chresmoda.

Carpenter (1992) considered Chresmoda obscura as a species of an uncertain Orthoptera family and separated it from Propygolampis gigantea (Germar, 1839). Following Handlirsch (1906-1908), Rasnitsyn (2002) indicated that it is "safer to consider Propygolampis Weyenbergh, 1874 as a junior synonym of Chresmoda".

Our new material adds little to the enigmatic position of the family Chresmodidae within the Polyneoptera, except for the fact they are definitely not Hemiptera because of their well-developed non-sucking mandibles.

Chresmoda libanica differs from the adult of $C$. obscura and the adult and the larva of $C$. aquatica in its very short prothoracic tibia $(23 \%$ of femoral length instead of $43 \%$ in the adult of C. obscura and in the larva of C. aquatica) (Martínez-Delclòs, 1991: Fig. 6.6.8).

Chresmoda obscura is supposed to have only fivesegmented tarsi (Ponomarenko, 1985: 140), unlike $C$. aquatica and $C$. libanica, but this interpretation is due to the bad preservation of all the specimens described for this species, as already proposed by Martínez-Delclòs (1991: 452). After the examination of the adult specimen
MNHN-LP-B 49008 (Laboratoire de Paléontologie, Muséum National d'Histoire Naturelle, Paris, France), Chresmoda obscura has 3-4 longer basal tarsomeres and at least 7-8 very small apical tarsomeres on prothoracic and mesothoracic legs (but poorly visible in metathoracic legs). The state of preservation of this specimen does not permit getting more precise information on the exact number of tarsomeres in C. obscura. Thus $C$. obscura seems to have tarsi very similar to those of $C$. aquatica (see Martínez-Delclòs, 1991).

Martínez-Delclòs (1991) added that some specimens housed in the Jura-Museum of $C$. obscura have visible tarsal claws, unlike $C$. aquatica and $C$. libanica sp. n. Only the discovery of new, well-preserved, material of $C$. obscura will shed some light on this point.

Chresmoda orientalis is based on a unique adult specimen, shorter than the adults of $C$. obscura, with longer antennae and shorter wings, extending only as far back as the apex of cerci. We have no accurate knowledge about its tarsal structures but, after the photograph of the holotype, it has very long legs, with the tarsi more or less curved apically (Esaki, 1949: pl. 1), suggesting the presence of numerous apical tarsomeres. Its prothoracic tibiae are longer than in C. libanica (32\% of the length of the femora after the original photograph of the holotype).

Saurophthiroides mongolicus has short and sharp cerci similar to those of $C$. libanica sp. n. (Ponomarenko, 1986: 110-111, text-fig. 84, pl. 10, Fig. 2). The only visible difference is the absence of visible ovipositor in the former, but this is probably due to fact that its known nymphs were males or younger specimens. The tarsal structures of Saurophthiroides mongolicus are unknown. Its prothoracic tibiae are longer than in $C$. libanica (about 36\% of the length of the femora after the original photograph of the holotype).

Rasnitsyn (2002: 256) indicated, based on pers. comm. of Zherikhin and Shcherbakov, that Saurophthiroides mongolicus (earlier Early Cretaceous, Gurvan-EreniyNuru, Mongolia) is probably a chresmodid larva "because of a somewhat similar general appearance". This last taxon is not well defined because the only known specimen is rather poorly preserved (Ponomarenko, 1986: pl. 10, Fig. 2a, b). There is no clear argument to support a generic separation between Saurophthiroides and Chresmoda. The comparison of Saurophthiroides mongolicus with the other Chresmodidae cannot be made accurately. We consider Saurophthiroides mongolicus as a probable Chresmodidae incertae sedis stat. $\mathrm{n}$.

\section{PALAEOECOLOGY OF THE CHRESMODIDAE}

The four specimens of $C$. libanica $\mathrm{sp}$. n. correspond to nymphal exuviae because of the presence of a dorsal thoracic aperture corresponding to an exdysial line in specimens NI 1 and NI 2. Three of them are females, probably last instars, because of the presence of well-developed ovipositors. The absence of any trace of wing sheaths suggests that $C$. libanica $\mathrm{sp}$. n. could have been apterous, because the wing sheaths are well developed in the polyneopteran last instars. But nothing is certain concerning 


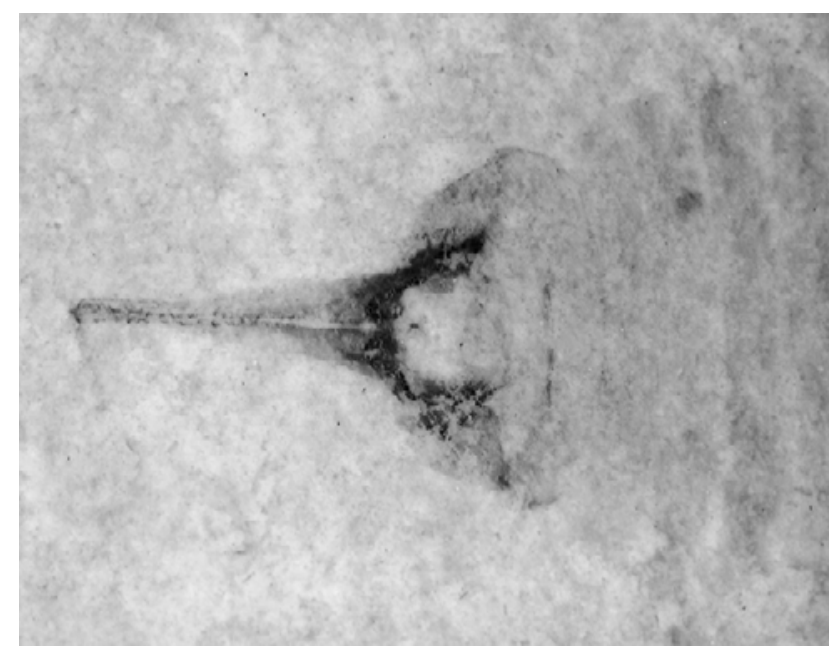

Fig. 5. Chresmoda libanica sp. n., holotype specimen NI 3a, photograph of ovipositor.

this last point. Interestingly, Martínez-Delclòs (1991) demonstrated that adult males of $C$. aquatica and $C$. obscura were apterous, suggesting that also the adult females of $C$. libanica could have been apterous.

The presence of unique, highly specialized tarsi in $C$. obscura, C. aquatica, C. libanica sp. n., and probably $C$. orientalis strongly supports the hypothesis that these insects were living on the water surface, using the water superficial tension to "skate" on surface like extant Gerridae and Veliidae, as already proposed by MartínezDelclós (1991). Baudoin (1980) tried to establish that Chresmoda obscura could not live on water surface, using the water superficial tension, through a comparison with the extant Gerridae. He supposed that the Chresmoda were too large to float like Gerridae. But nobody knew in 1980 that at least some Chresmoda spp. could have highly specialized legs and tarsi. Numerous extant Gerridae bear highly specialized setae that help them to float by increasing their surface in contact with water surface (Andersen, 1982). Chresmoda aquatica and Chresmoda libanica $\mathrm{sp}$. $\mathrm{n}$. have no specialized setae on their legs but their exceptionally high number of tarsomeres (about 40 in C. libanica sp. n., about twelve in C. obscura and $C$. aquatica) probably helped to increase, thanks to the curvature of the tarsi, the length of that part of the leg in contact with the water surface, and consequently to increase the vertical component of the superficial tension

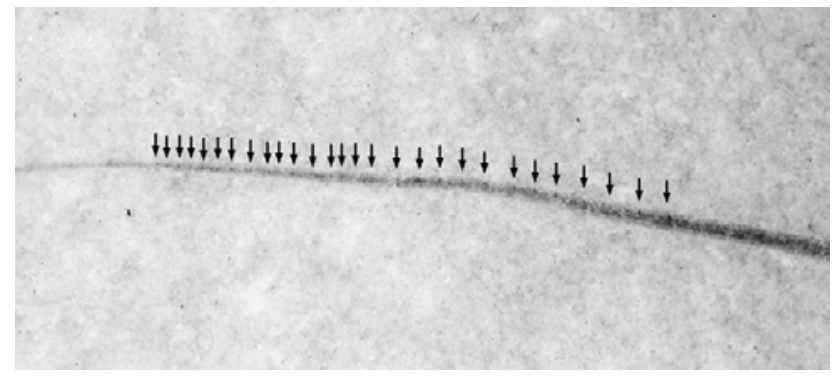

Fig. 7. Chresmoda libanica sp. n., holotype specimen NI 3a, photograph of left median tarsus, arrows indicate tarsomeres.

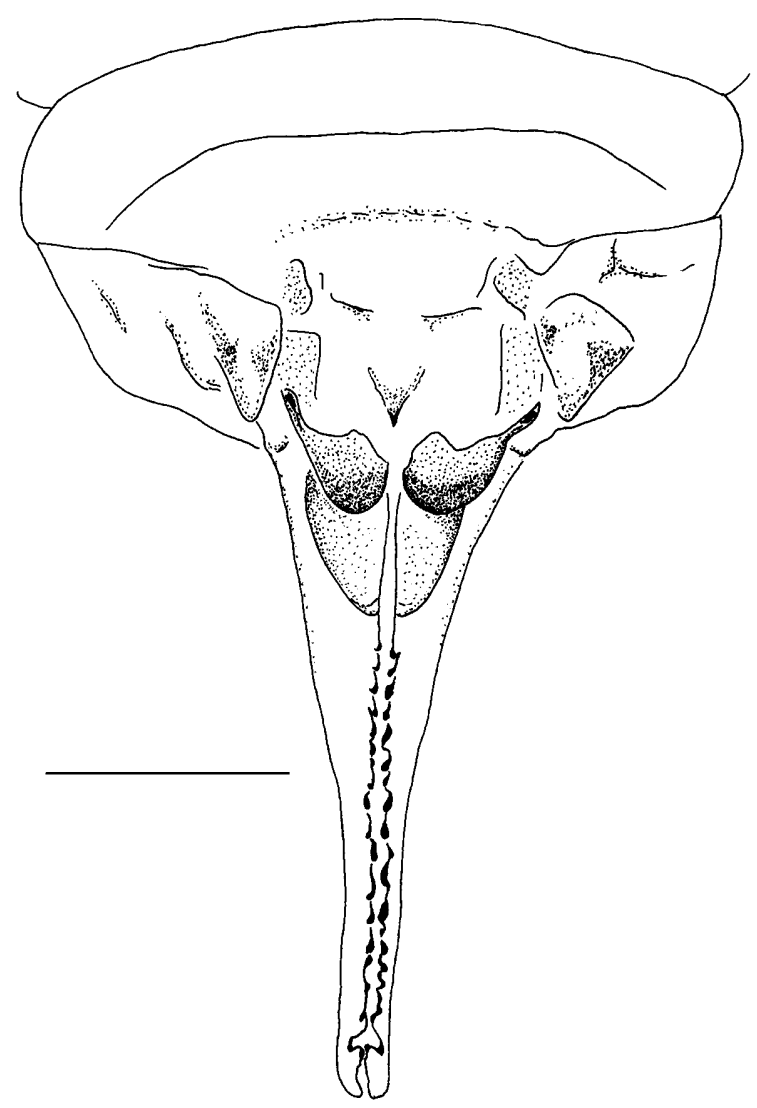

Fig. 6. Chresmoda libanica sp. n., holotype specimen NI 3a, drawing of ovipositor, scale bar represents $1 \mathrm{~mm}$.

(Baudoin 1980: 2). The oblique apices of the tarsomeres probably acted as a blocking system in order to avoid the complete distortion of the legs (see Figs 7-8, 13). Similarly, some Gerridae such as Potamobates thomasi Hungerford, have no specialized setae but their two-segmented tarsi are curved (Andersen, 1982: Fig. 438).

Nevertheless, the Chresmodidae probably did not use their legs for skating in the same way as modern Gerridae and Veliidae do. These insects have short to very short fore legs, useless in skating, and they mainly use their median and partly hind legs for this purpose. The fore, mid and hind legs of the Chresmodidae have nearly the same lengths and structures, and so probably similar functions in skating.

C. aquatica, Saurophthiroides mongolicus, and the Chresmodidae from Araripe (Lower Cretaceous of Brazil) probably lived in lacustrine palaeoenvironments. The Solnhofen lithographic limestone was a marine deposit, but it has yielded numerous fossils of terrestrial origin. The Nammoura "fish beds" are also of marine origin

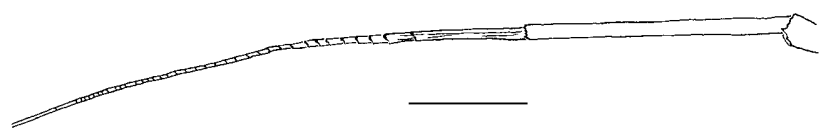

Fig. 8. Chresmoda libanica sp. n., holotype specimen NI 3a, drawing of left median tibia and tarsi, scale bar represents 3 $\mathrm{mm}$. 


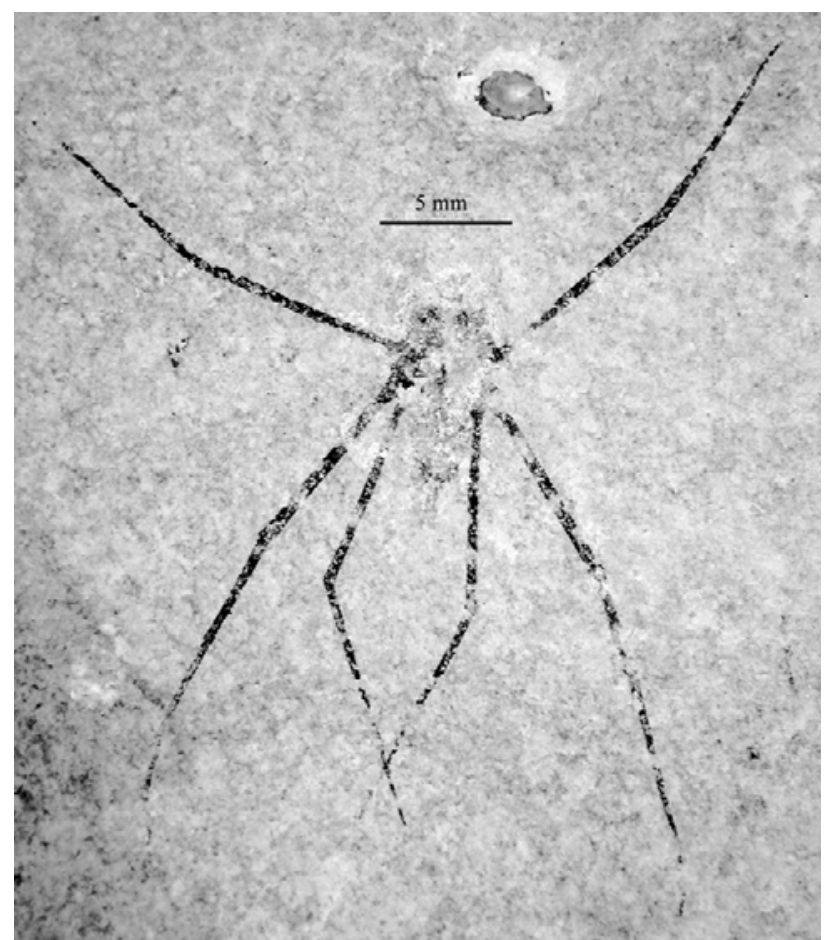

Fig. 9. Chresmoda libanica sp. n., paratype specimen NI 2b, photograph of general habitus.

(Schram et al., 1999), but with "a considerable influx of terrestrial organic debris" (Krassilov and Bacchia, 2000: 798). Thus both $C$. obscura and $C$. libanica sp. n. could have been marine or freshwater insects.

The long ovipositor with indentations of $C$. libanica sp. n., already observed in C. aquatica by Martínez-Delclós (1991: Fig. 6.6.7), can be related to an endophytic egglaying in floating plants, for example palustrine or marine algae. Six to eight different plant taxa of this kind were present in the outcrop of Nammoura (Makhoul, pers. obs.). Nammouria gracilis Krassilov, 2000 is an aquatic fern with floating leaf segments described from Nammoura (Krassilov and Bacchia, 2000). Thus, the suggested endophytic egg-laying of $C$. libanica sp. n. does not exclude a freshwater origin for this insect. Neverthe-

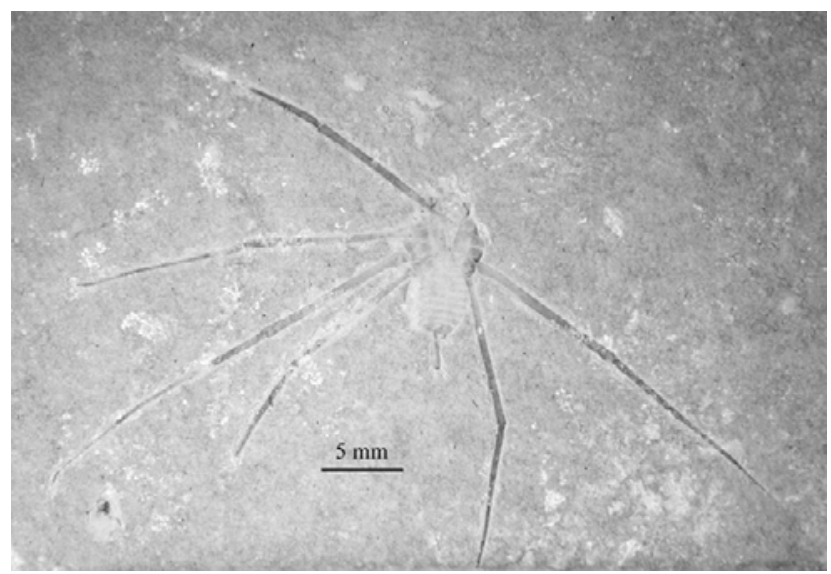

Fig. 11. Chresmoda libanica sp. n., paratype specimen NI 1b, photograph of general habitus.

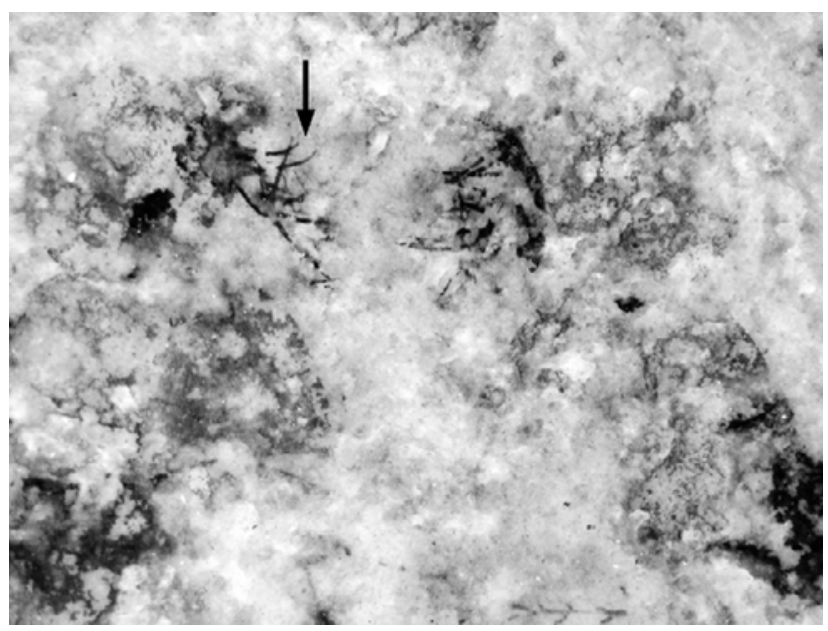

Fig. 10. Chresmoda libanica sp. n., paratype specimen NI 2b, photograph of maxillary palpi, arrow indicates some of the long and sharp spines of a palpus.

less, two of the three known specimens of $C$. libanica sp. n. are well-preserved nymphal exuviae, which are very delicate remains that do not support long transport. This suggests that these nymphs were living in the sea or very close to it.

C. libanica sp. n. was probably carnivorous since it shows well-developed maxillary palpis, as in C. aquatica, bearing numerous strong and sharp spines and it has strong mandibles. It would probably eat small insects trapped by the water surface tension, or planktonic or nektonic animals when they came to the surface, maybe the larvae of the abundant fauna of Crustaceae (Schram et al., 1999). Nothing was known until now concerning the mouthparts and the alimentation of the Chresmodidae. Baudoin (1980: 116) proposed that the Chresmodidae were herbivorous, and thus they would have nothing to eat if they had been surface skaters. From our point of view, this argument is not valid because of the existence of freshwater and marine floating plants in the Cretaceous. Furthermore, the present discovery allows us to reject Baudoin's argument.

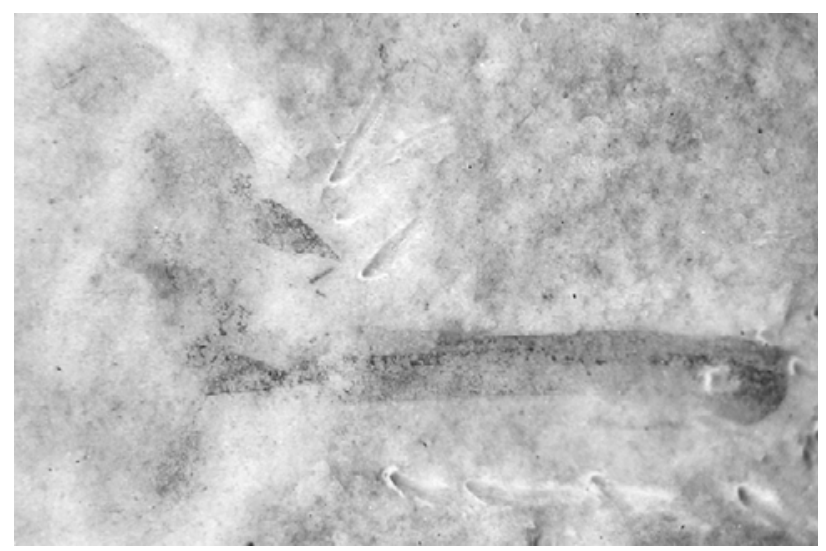

Fig. 12. Chresmoda libanica sp. n., paratype specimen NI 1, photograph of cerci and ovipositor. 


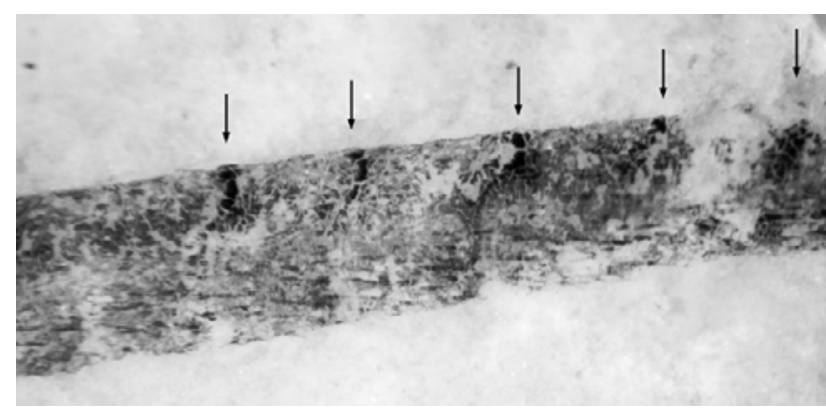

Fig. 13. Chresmoda libanica sp. n., paratype specimen NI 1, photograph of right median tarsus, arrows indicate oblique apices of tarsomeres.

The legs of the Chresmodidae bearing numerous tarsomeres constitute a highly specialized, unique feature among the Hexapoda. Interestingly, the two basal tarsomeres are of "normal size". Distal tarsomeres are very short and seem to result from a multiple subdivision of the 2-3 normal ones. The most apical tarsomeres are "drop-like" shaped, looking like antennomeres rather than tarsomeres. Nevertheless, the intermediate tarsomeres have retained the same oblique joints as the two basal ones. Lastly, these legs lack apical claws. These tarsi have the general shape of antennae. We can hypothesize the occurrence of a mutation, maybe homeotic or affecting some genes that participate to the leg development, resulting in the transformation of the distal part of the legs into "antennae". Such mutations have been artificially induced in Drosophila sp. (holometabolous Diptera) (Struhl, 1981, among other authors). It is impossible to establish the mechanisms that precisely explain the phenomenon in fossil Chresmodidae, but the major leg mutation that affected the Chresmodidae is a unique phenomenon among the Hexapoda. The reduction of the number of tarsomeres is much more frequent in the insects. The number of tarsomeres increased from the older, Upper Jurassic, Chresmoda obscura to the Lower Cretaceous C. aquatica, and the most recent, Upper Cretaceous, $C$. libanica, just as if, after the occurrence of a major fundamental mutation in the Jurassic lineage of the Chresmodidae, less important mutations of the same type had resulted in more and more numerous tarsomeres in the most recent taxa of the group. It would be interesting to study the mutations transforming legs into antennae in extant Orthoptera or Phasmida, potential closest relatives to the Chresmodidae.

Chresmoda libanica sp. $\mathrm{n}$. is the most recent representative of the Chresmodidae, which probably became extinct during the Upper Cretaceous. The oldest aquatic insects attributed to the families Mesoveliidae and Veliidae are 120 Myr old. The same minimal age can be hypothesized for the Gerridae, as sister group of the Veliidae (Andersen, 1999). The recent discovery of a representative of the Gerridae in the Upper Albian French amber confirms the presence of Gerridae and Veliidae in the Lower Cretaceous (Perrichot et al., submitted). Thus the Chresmodidae and the freshwater surface skater bugs were contemporaneous during at least the Albian and

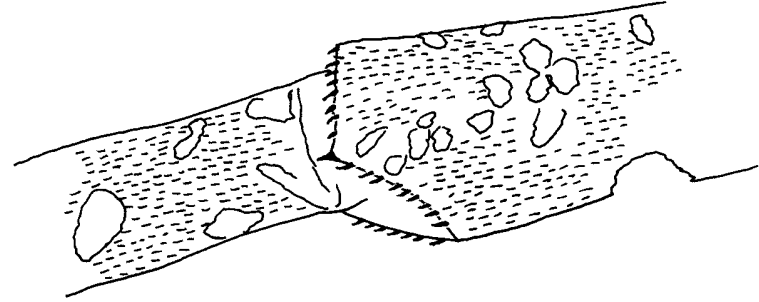

A

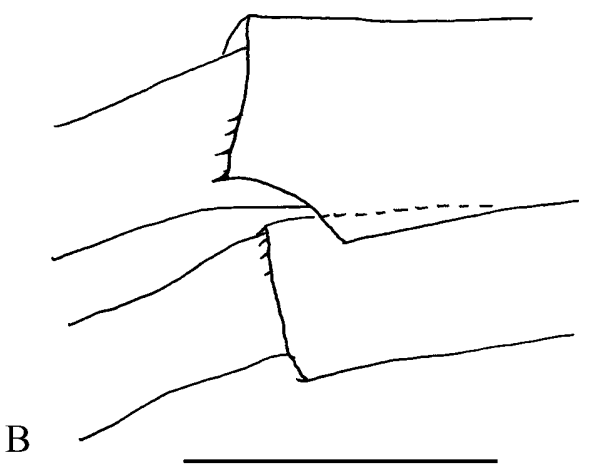

Fig. 14. Chresmoda libanica sp. n., apices of tibiae. A. Paratype specimen NI 1b, median leg. B. Holotype specimen NI 3, left median and left hind legs, scale bar represents $1 \mathrm{~mm}$.

Cenomanian, if not all the Lower Cretaceous. These bugs did not "replace" and did not cause the extinction of the Chresmodidae, at least in freshwater environments. The oldest known marine water strider is from the Middle Eocene of Italy (Andersen et al., 1994). Thus, it is still not possible to demonstrate the existence of marine water striders during the Upper Cretaceous that would have "replaced" the alleged marine Chresmodidae. The extinction of this curious Mesozoic group is still unexplained.

ACKNOWLEDGEMENTS. This study was a contribution from the Scientific Projects PGC 2001-0173 and PGC 2001-0185 (Spain), and Project CEDRE between France and Lebanon 02 E F12 / L11 "Les entomofaunes crétacés du Liban: apport à la reconstitution des paléoclimats et Paléoenvironnements".

\section{REFERENCES}

ANDERSEN N.M. 1982: The semiaquatic bugs (Hemiptera: Gerromorpha): phylogeny, adaptations, biogeography and classification. Entomonograph. Scandinavian Science Press, Klampenborg, Denmark, 3: $445 \mathrm{pp}$.

ANDERSEN N.M. 1999: The evolution of marine insects: phylogenetics, ecological, and geographical aspects of species diversity in marine water striders. Ecography 22: 98-111.

Andersen N.M., Farma A. Minelli A. \& Piccoli G. 1994: A fossil Halobates from the Mediterranean and the origin of sea skaters (Gerridae). Zool. J. Linn. Soc. 112: 479-489.

BAUDOIN R. 1980: Sur les Gerris des miroirs d'eau actuels et les Chresmoda des lagunes post-récifales portlandiennes de Solnhofen. Annls Sci. Natur., Zool.-Biol. Anim. 2: 111-116.

CARpenter F.M. 1992: Superclass Hexapoda. In: Moore R.C. \& Kaesler R.L. (eds): Treatise on Invertebrate Paleontology. The Geological Society of America and the University of Kansas, Boulder, Colorado, (R), Arthropoda 4, 3/4: xxii +655 pp.

EsAKI T. 1949: The occurrence of the Mesozoic insect Chresmoda in the Far East. Insecta Matsumurana 17: 4-5. 
FricKHINGER K.A. 1994: The Fossils of Solnhofen. Goldschneck Verlag, Korb, pp. 5-336.

Handlirsch A. 1906-1908: Die Fossilen Insekten und die Phylogenie der Rezenten Formen. Ein Handbuch für Paläontologen und Zoologen. 1430 pp. (Engelman, V.W. publ., Leipzig) [published in parts between 1906 and 1908 as follows: pp. i-vi, 1-160, pls. 1-9 (May 1906); pp. 161-320, pls. 10-18 (June 1906); pp. 321-480, pls. 19-27 (August 1906); pp. 481-640, pls. 28-36 (October 1906); pp. 641-800, pls. 37-45 (February 1907); pp. 801-960, pls. 46-51 (June 1907); pp. 961-1120 (November 1907); pp. 1121-1280 (January 1908); pp. vii-ix, 1281-1430 (July 1908). Dated from publication information given on p. ix.]

Krassilov V. \& Bacchia F. 2000: Cenomanian florule of Nammoura, Lebanon. Cretac. Res. 21: 785-799.

Martínez-Delclòs X. 1989: Chresmoda aquatica n. sp. insecto Chresmodidae del Cretácico inferior de la Sierra del Montsech (Lleida, España). Revta Esp. Paleontol. 4: 67-74.

Martínez-Delclòs X. 1991: Insectes Hemimetàbols del Cretaci Inferior d'Espanya. Tafonomia i Paleoautoecologia. Tesi Doctoral, Departament de Geologia Dinàmica, Geofisica i Paleontologia, Universitat de Barcelona, 784 pp.
Ponomarenko A.G. 1985: Fossil insects from the Tithonian "Solnhofener Plattenkalke" in the Museum of Natural History, Vienna. Annln Naturh. Mus., Wien 87: 135-144.

PonomarenKo A.G. 1986: Scarabaeiformes incertae sedis. pp. 110-112. In: Rasnitsyn A.P. (ed.): Insects in the Early Cretaceous Ecosystems of West Mongolia. Trudy Sovmest. Sov.-Mongol. Paleontol. Ehksped. 28: 213 pp. [in Russian.]

RASNITSYN A.P. 2002: Chapter 2.2.2. Infraclass Gryllones Laicharting, 1781. The Grylloneans (= Polyneoptera Martynov, 1938). pp. 254-262. In: Rasnitsyn A.P. \& Quicke D.L.J. (eds): History of Insects. Kluwer Academic Publishers, Dordrecht, Boston, London, xi $+517 \mathrm{pp}$.

Rasnitsyn A.P. \& Martínez-Delclòs X. 2000: Wasps (Insecta: Vespida $=$ Hymenoptera) from the Early Cretaceous of Spain. Acta Geol. Hispan. 35: 65-95.

Schram F.R., Hof C.H.J. \& SteEman F.A. 1999: Thylacocephala (Arthropoda: Crustacea?) from the Cretaceous of Lebanon and implications for thylacocephalan systematics. Palaeontology 42: 769-797.

StRUHL G. 1981. A homoerotic mutation transforming leg to antenna in Drosophila. Nature 292: 635-638.

Received March 28, 2003; revised July 25, 2003; accepted October 8, 2003 